\title{
Medium optimization for enhanced growth of Bacillus subtilis SRCM102046 possessing antibacterial activity using response-surface methodology
}

\author{
Gwangsu $\mathrm{Ha}^{1}$, Hee-Jong Yang ${ }^{1}$, Su-Ji Jeong ${ }^{1}$, Myeong Seon Ryu ${ }^{1}$, JinWon Kim ${ }^{1}$, \\ HoYeon Yang ${ }^{1}$, Su-Jin Shin ${ }^{2}$, Sua $\mathrm{Im}^{1}$, Ji Won Seo ${ }^{1}$, \\ Seong-Yeop Jeong ${ }^{1}$, Do-Youn Jeong ${ }^{1 *}$ \\ ${ }^{1}$ Microbial Institute for Fermentation Industry (MFI), Sunchang 56048, Korea \\ ${ }^{2}$ Korean Culture Center of Microorganisms (KCCM), Sunchang 56048, Korea
}

\section{반응표면분석법을 이용한 항균활성을 가지는 Bacillus subtilis SRCM102046의 균체 증량을 위한 배지 최적화}

\author{
하광수 ${ }^{1} \cdot$ 양희종 ${ }^{1} \cdot$ 정수지 $^{1} \cdot$ 류명선 $^{1} \cdot$ 김진원 $^{1} \cdot$ 양호연 $^{1} \cdot$ 신수진 $^{2} \cdot$ 임수아 $^{1} \cdot$ \\ 서지원 ${ }^{1} \cdot$ 정성엽 $^{1} \cdot$ 정도연 ${ }^{1 *}$ \\ ${ }^{1}($ 재 $)$ 발효미생물산업진흥원, ${ }^{2}$ 한국미생물종균협회
}

\begin{abstract}
The aim of this study was to investigate the optimal conditions for increasing the growth yield of Bacillus subtilis SRCM102046, a strain possessing potential biopreservative properties. B. subtilis SRCM102046 showed remarkable antibacterial activity against a wide range of bacterial foodbome pathogens that cause serious food spoilage, as well as high antioxidant capacity. Response-surface methodology (RSM) was used to optimize medium composition to enhance B. subtilis SRCM102046 biomass. The effects of 14 different components on biomass production were investigated and three significant positive factors, molasses, sucrose, and peptone, were selected as the main factors for improving biomass based on a Plackett-Burman design (PBD). Next, we optimized the concentrations of these three factors using a central composite design. The predicted optimized concentrations were $7 \mathrm{~g} / \mathrm{L}$ molasses, 7 $\mathrm{g} / \mathrm{L}$ sucrose, and $2 \mathrm{~g} / \mathrm{L}$ peptone. The coefficient of determination $\left(\mathrm{R}^{2}, 0.9755\right)$ for the model and probability value showed that our model was highly significant. Finally, an overall approximate 9-fold increase in dry cell weight yield $(22.03 \mathrm{~g} / \mathrm{L})$ was achieved using the optimized medium compared with the non-optimized medium $(2.47 \mathrm{~g} / \mathrm{L})$. Furthermore, we confirmed that the antibacterial activity and antioxidant activity also increased by $140 \%$ and $100.41 \%$, respectively. These research is expected to be useful data for the production of food preservatives by establishing optimal conditions for increasing the growth yield of microorganisms possessing excellent antimicrobial activity.
\end{abstract}

Key words : Bacillus subtilis, antimicrobial activity, medium optimization, biopreservative, response surface methodology

서 론

*Corresponding author. E-mail : jdy2534@korea.kr

Phone : 82-63-650-2000, Fax : 82-63-650-9590

Received 13 July 2018; Revised 16 August 2018; Accepted 20 August 2018.

Copyright (c) The Korean Society of Food Preservation. All rights reserved.
화학합성 식품첨가물의 사용으로 인한 부작용이 지속적 으로 대두되면서 합성물질보다는 천연물질을 선호하는 경 향이 나타나고 있으며, 이에 따라 천연물을 식품보존제로 이용하려는 다양한 연구가 진행되고 있다(1,2). 우리나라는 전통적으로 된장이나 청국장과 같은 콩 발효식품, 김치, 젓갈 등 미생물을 이용한 발효식품이 풍부하나 전통발효식 품 대부분이 염분의 함량이 높아 고혈압, 뇌졸중과 같은 성인병 등의 예방을 이유로 저염화 추세가 두드러지고 있다 
(3). 하지만 발효식품을 저염화 할 경우 다양한 부패미생물 의 증식으로 보존성이 낮아지고, 이상발효가 일어날 가능 성에 대한 문제가 발생한다(3). 이러한 문제를 해결하기 위해 aflatoxin을 생산하는 곰팡이(4) 또는 구토형 독소를 생산하는 것으로 알려진 Bacillus cereus에 대한 길항작용 활성을 갖는 미생물 대한 다양한 연구(5)들이 진행되고 있다.

기존의 항생제가 2 차 대사산물인데 반하여 박테리오신 은 리보솜에서 합성된 펩타이드로 이루어져 인체 소화기관 내의 단백질 가수분해효소에 의해 분해되므로 인체에 무독 성이며, 잔류성이 없다는 점에서 의약품 및 식품의 천연보 조제로서의 잠재성이 증대되고 있다(6,7). 미생물이 생산하 는 대표적인 항생물질로 Lactococcus lactis가 생산하는 nisin이라 명명된 박테리오신은 1998년 미국 food and drug administration(FDA)의 승인으로 전 세계에서 천연식품보 존제로 사용되고 있으나 유산균 유래의 박테리오신은 그람 음성균이나 효모, 곰팡이에 대한 항균력이 거의 없다는 점 (6)과 낮은 $\mathrm{pH}$ 나 중성에서 활성이 약하다고 보고(8)되고 있어 식품보존제로서의 한계성이 드러나고 있다. 이에 반 해 Bacillus 종이 생산하는 항균물질은 식품유해미생물에 대한 넓은 범위의 항균성을 나타내고(9), 다양한 구조를 지니는 펩타이드성 또는 단백질성이며, 넓은 $\mathrm{pH}$ 범위와 온도 조건에서도 항균활성이 유지된다는 연구결과들 (10-12)이 보고되고 있다. 최근 건강과 식품의 안전에 대한 요구가 증가됨에 따라 안전성이 보장된 generally recognized as safety(GRAS) 등급의 Bacillus(B. subtilis, B. coagulans, B. licheniformis) 균주 유래 항균 물질 중 유산균 박테리오신 의 한계를 극복할 수 있는 천연식품보존제로서의 효용 가치 가 부각되고 있다.

이러한 활용가치가 큰 미생물을 산업적으로 이용하고자 할 때는 균주의 배양조건 확립이 필수적이다. 미생물 유래 대사산물의 생산 효율은 물리적인 조건이나 배양 시간, 배 지 성분 조절 등에 의해 향상될 수 있다(13). 최근에는 미생 물 배양을 위한 배지 조성의 최적조건을 탐색할 때 가장 효과적인 방법으로 반응표면분석법(RSM, response surface methodology)이 사용되고 있는데, 이는 실험 경비의 절약, 각 요인들의 상호작용을 통한 결과의 최소치와 최대치의 결과를 동시에 예측할 수 있는 장점을 가지고 있다(14).

본 연구실에서는 선행연구를 통해 충청도 시, 군에서 수 집한 174 개의 전통발효 식품으로부터 574종의 후보 균주를 분리하였으며, 넓은 범위의 식품유해미생물에 대한 항균활 성과 항산화 활성이 가장 우수한 SRCM102046을 최종 선별 하였다(data not shown). 따라서 본 연구에서는 선행 연구를 통해 식중독 또는 식품부패를 일으키는 것으로 알려진 $B$. cereus, Vibrio parahaemolyticus, Listeria monocytogenes 등 에 대한 높은 항균활성과 항산화능이 우수한 SRCM102046 을 식품보존 소재로서 산업적 활용 가치를 높이기 위해
균체 증량을 위한 배양 조건을 확립하고자 하였으며, 최종 확립된 배양 조건에서의 항균 및 항산화능을 측정하여 식품 보존 소재로서의 기능성 향상 또한 도모하고자 하였다.

\section{재료 및 방법}

\section{미생물의 배양}

전통방법으로 제조된 된장으로부터 분리한 SRCM102046 균주의 배양은 Luria-bertani(LB, Difco, Sparks, MD, USA) 에 $5 \%$ 전배양액을 접종하여 $30^{\circ} \mathrm{C}$ 에서 $150 \mathrm{rpm}$ 으로 24 시간 행하였다.

\section{$16 S$ rRNA 염기서열 분석}

SRCM102046을 동정하기 위해 $16 \mathrm{~S}$ rRNA 유전자의 염기 서열을 분석하였다. 서열 증폭을 위해 universal primer인 $27 \mathrm{~F}$ ( 5' - AGAGTTTGATCCTGGCTCAG-3') 와 1492R(5'-GGTTACCTTGTTACGACTT-3') primer를 사용 하였으며, National Center for Biotechnology Information (NCBI)에서 서열의 일치도가 높은 표준균주들의 $16 \mathrm{~S}$ rRNA 유전자 서열을 얻었다. 서열간의 상호 비교를 위해 Clustal W 2.0 program(EMBL-EBI, Hinxton, Cambridgeshire, $\mathrm{UK}$ )을 사용하였으며, Mega 7.0.26 program을 이용하여 계 통도를 작성하였다. 계통도 분석에는 근린결합법(neighborjoining method)(15)을 사용하였으며, 계통수의 신뢰도를 확 인하기 위해 bootstrap 분석을 1,000 회 시행하였다.

\section{배양시간에 따른 균체 성장 조사}

SRCM102046의 배양시간에 따른 성장을 조사하기 위해 Yang 등(16)의 방법을 이용하여 $100 \mathrm{~mL} \mathrm{LB(Difco)}$ 액체배 지에 $5 \%$ 의 전배양액을 접종한 후 60 시간 동안 $30^{\circ} \mathrm{C}, 150$ $\mathrm{rpm}$ 에서 배양하고, 4시간 간격으로 배양액을 회수하여 흡 광도와 건조 균체량 $(\mathrm{DCW}$, dry cell weight)을 측정하였다. 흡광도는 회수한 배양액 $1 \mathrm{~mL}$ 을 UV/VIS spectrophotometer (SPECORD 200, Analytic jena, Jena, Germany)를 이용하여 $600 \mathrm{~nm}$ 에서 측정하였으며, 건조 균체량은 4시간 단위로 배양액 $10 \mathrm{~mL}$ 을 회수하여 $13,000 \mathrm{rpm}$ 에서 15 분간 원심분리 한 후 멸균 증류수로 3 회 세척하고 $80^{\circ} \mathrm{C}$ 에서 항량에 도달할 때까지 건조하여 균체의 무게를 측정하였다.

\section{반응표면분석법을 이용한 배지조성의 최적화}

SRCM102046의 최대 균체량을 생산하기 위한 최적 배지 조성을 설정하기 위한 방법으로 반응표면분석법을 실시하 였다. 선행연구를 통해 선별한 14 개의 배지 성분 중 균체 증량에 주효과가 있는 3 개의 성분을 선별하기 위해 Plackett-Burman design(PBD)을 이용하였다(16). PBD 실험 계획법에 따라 각 독립변수는 Table 1 에 제시하였으며, 변 
Table 1. Range of different variables for the Plackett-Burman design (PBD) and results for response value (dry cell weight)

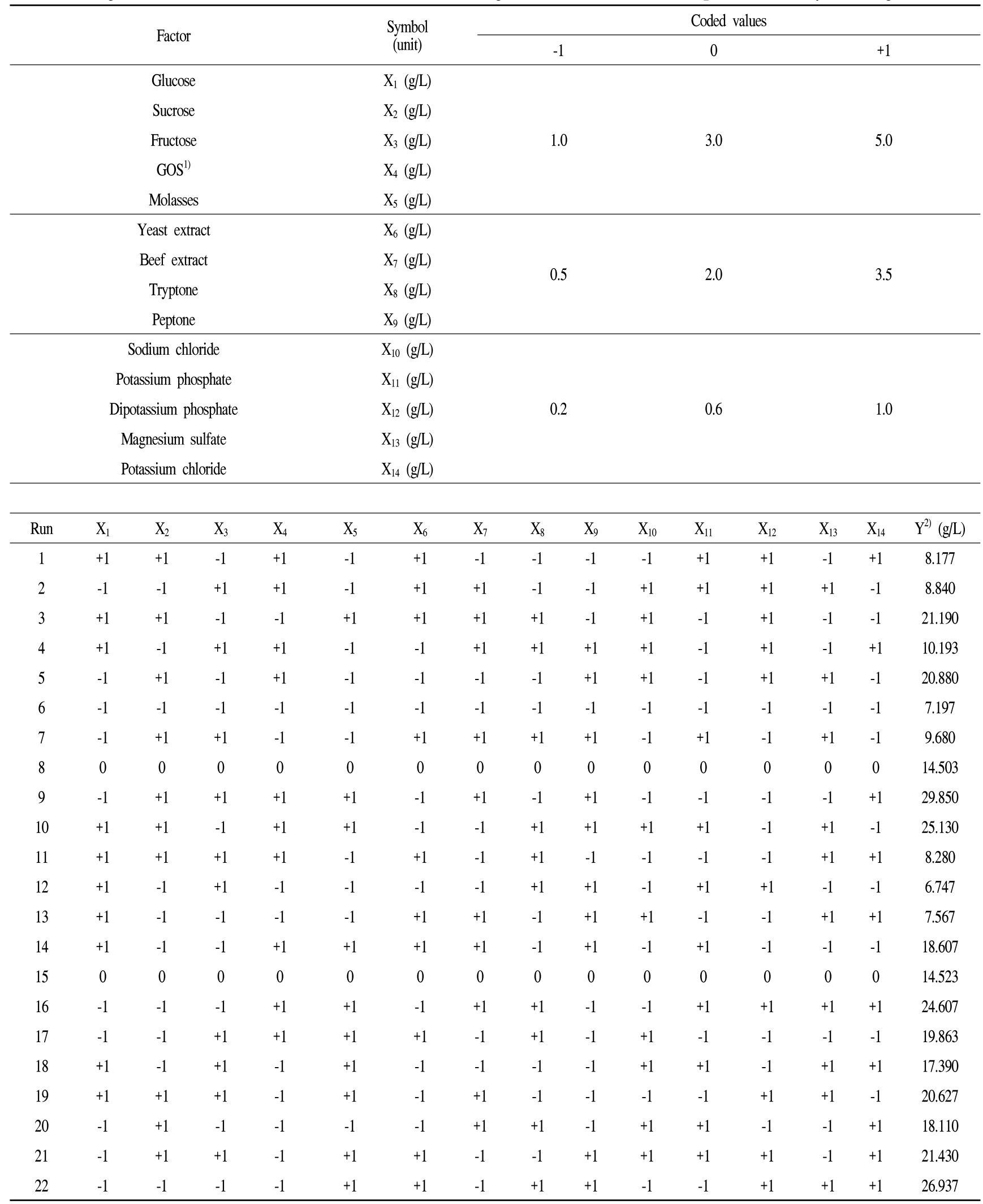

All experiments were performed in triplicate.

${ }^{1)} \mathrm{GOS}$, galacto-oligosaccharide.

${ }^{2} \mathrm{Y}$, response value, dry cell weight of B. subtilis SRCM102046 
수의 수준을 $-1,0,+1$ 로 부호화하였다. 종속변수로는 건조 균체량 $(\mathrm{Y}, \mathrm{g} / \mathrm{L})$ 을 설정하였으며, 2 개의 중심점을 포함한 실험모델을 계획하였다. 모든 실험구의 값은 3회 반복 측정 을 통해 평균값을 산출하였으며, 실험 계획과 데이터 분석 은 Design expert 9.0(Version 9.0.3.1, Stat-Ease Inc., Minneapolis, MN, USA) program을 사용하였다. PBD를 통 해 선별된 배지 성분의 균체 증량을 위한 최적 농도를 결정 하기 위해 배지성분 각각의 농도 변화가 균체량에 미치는 영향을 central composite design(CCD)을 이용하여 분석하 였다(16). PBD 실험계획에 의한 실험 결과를 기반으로 중심 값과 변수의 수준을 $-2,-1,0,+1,+2$ 로 부호화 하였고 16 개 의 실험구로 이루어진 중심합성계획법을 실시하였다. 중심 점 2회를 포함한 16 개의 실험구를 3회 반복 실험을 통한 평균값을 회귀분석에 사용하였으며, 이때의 독립변수와 종 속변수에 대한 2 차 회귀 모형식은 아래와 같다.

$$
Y=\beta_{0}+\sum \beta_{i} X_{i}+\sum \beta_{i i} X_{i}^{2}+\sum \beta_{i j} X_{i} X_{j}
$$

여기에서 $\mathrm{Y}$ 는 종속변수, $\mathrm{Xi}$ 는 독립변수, $\beta_{0}$ 는 상수계수, $\beta_{\mathrm{i}}, \beta_{\mathrm{ii}}$, 그리고 $\beta_{\mathrm{ij}}$ 는 교호작용 계수를 나타낸다. Design expert 9.0 program을 이용하여 회귀분석에 의한 모델식을 예측하였고 회귀분석 결과를 바탕으로 임계점 분석 및 균체 증량을 위해 선별된 3 개 성분의 최적 농도를 결정하으며, analysis of variance(ANOVA) 분석을 통해 통계적 유의성을 검정하였다.

\section{식품유해 미생물에 대한 항균 활성 측정}

SRCM102046의 항균활성 측정에 사용된 지시균주는 한 국생명공학연구원 생물자원 센터(KCTC, Korean collection for type cultures)와 한국미생물종균협회(KCCM, Korean culture center of microorganisms)에서 분양 받아 사용하였 으며, 각 지시균주의 배양조건은 Table 2에 나타내었다. Gram 양성균 8종과 음성균 6종, Aspergillus flavus 2종에 대한 항균활성을 측정하기 위해 지시균주가 포함되어있는 $0.8 \%$ soft agar 배지를 이용한 well-diffusion 방법(17)으로 측정하였다. $\mathrm{LB}(\mathrm{Difco})$ 배지와 실험모델에 의해 예측된 최 적배지에 배양액 $5 \%$ 를 접종하여 $30^{\circ} \mathrm{C}, 150 \mathrm{rpm}$ 에서 24 시간 동안 배양한 후 각각의 배양상등액 $100 \mu \mathrm{L}$ 를 $0.45 \mu \mathrm{m}$ syringe filter(Toyo Roshi Kaisha, Ltd., Tokyo, Japan)로 여과 한 후 지시균주가 포함된 배지에 형성된 직경 $8 \mathrm{~mm}$ 의 well 에 분주하여 gram 양성균과 음성균은 $30^{\circ} \mathrm{C}$ 에서 24 시간, Aspergillus flavus KCCM100910과 Aspergillus flavus var. flavus KCCM60330은 72시간 배양하였으며, 반응 후 well 주변에 형성된 억제환의 크기를 계측하여 항균활성을 평가 하였다.

\section{항산화(DPPH free radical scavenging) 활성 측정}

2,2-Diphenyl-1-picryl-hydrazyl(DPPH) 라디칼 소거활성 은 Blois의 방법(18)을 사용하여 측정하였다. SRCM102046 균주 배양액 $20 \mu \mathrm{L}$ 에 $0.1 \mathrm{mM}$ DPPH(Sigma-Aldrich, St. Louis, MO, USA) 용액 $180 \mu \mathrm{L}$ 을 가한 후 빛을 차단하여

Table 2. Strains used in this study as indicator for antimicrobial activity

\begin{tabular}{|c|c|c|c|}
\hline & Indicator organisms & Media $^{1)}$ & Temperature $\left({ }^{\circ} \mathrm{C}\right)$ \\
\hline \multirow{8}{*}{$\begin{array}{c}\text { Gram } \\
\text { positivie }\end{array}$} & Bacillus cereus KCTC3624 & LB & 30 \\
\hline & Bacillus cereus $\mathrm{KCCM} 40935$ & LB & 30 \\
\hline & Staphylococcus aureus KCCM11335 & TSB & 37 \\
\hline & Staphylococcus aureus KCCM40050 & LB & 37 \\
\hline & Enterococcus faecalis KCCM11814 & LB & 37 \\
\hline & Listeria monocytogenes KCCM43155 & BHI & 37 \\
\hline & Listeria ivanovii КСТС 3444 & BHI & 37 \\
\hline & Micrococcus luteus KCCM11211 & NB & 30 \\
\hline \multirow{6}{*}{$\begin{array}{c}\text { Gram } \\
\text { negative }\end{array}$} & Shigella flexneri КСТC2517 & LB & 37 \\
\hline & Shigella sonnei KCTC2518 & LB & 37 \\
\hline & Klebsiella pneumoniae КCСM40890 & NB & 37 \\
\hline & Vibrio parahaemolyticus KCCM11965 & TSB with $2.5 \% \mathrm{NaCl}$ & 37 \\
\hline & Escherichia coli $\mathrm{KCCM} 12177$ & LB & 37 \\
\hline & Salmonella typhimurium KCTC1926 & $\mathrm{LB}$ & 37 \\
\hline \multirow{2}{*}{ Mold } & Aspergillus flavus KCCM11910 & PDB & 30 \\
\hline & Aspergillus flavus var. flavus КССМ60330 & PDB & 30 \\
\hline
\end{tabular}

\footnotetext{
${ }^{1)} \mathrm{LB}$, Luria-Bertani broth; TSB, tryptone soy broth; $\mathrm{BHI}$, brain heart infusion broth; NB, nutrient broth; TSB with $2.5 \% \mathrm{NaCl}$, tryptone soy broth with $2.5 \%$ NaCl; PDB, potato
} dextrose broth. 
실온에서 30분간 방치하였으며, microplate reader(SPARK, TECAN, Grödig, Salzburg, Austria)를 사용하여 $517 \mathrm{~nm}$ 에서 흡광도를 측정하였다. 항산화 활성은 다음 식에 따라 백분 율(\%)로 표시하였으며 균주를 접종하지 않은 배지를 대조 구로 사용하였다.

DPPH free radical scavenging activity $(\%)=\left(1-\frac{\mathrm{AbS}_{\text {absorbance of sample }}}{\mathrm{Abs}_{\text {absorbance of control }}}\right) \times 100$

\section{결과 및 고찰}

\section{균주의 동정}

$\mathrm{SRCM} 102046$ 의 $16 \mathrm{~S}$ rRNA 유전자 염기서열 결과 $(1,521 \mathrm{bp})$ 를 이용하여 NCBI nucleotide BLAST(basic local alignment search tool) search를 수행하였다. GenBank에 등 록된 다른 균주들의 염기서열과 비교한 결과 B. subtilis strain DSM 10, B. subtilis strain BCRC 10255, B. subtilis strain IAM 12188 균주와 각각 $99.79 \%, 99.73 \%, 99.73 \%$ 의 상동성을 보여 B. subtilis SRCM102046으로 명명하였다. 분석된 염기서열을 바탕으로 phylogenetic tree를 작성하기 위해 evolutionary distance 추론은 neighbor-joining method 를 사용하였으며, 계통수의 신뢰도를 확보하기 위해 bootstrap 분석을 1,000회 시행하였다(Fig. 1). Earl 등(19)의 연구보고에 의하면 B. subtilis의 $16 \mathrm{~S}$ rRNA 유전자 서열은
약 $99.8 \%$ 의 높은 상동성을 갖지만 DNA-DNA reassociation analysis 결과 DNA relatedness가 58-69\%로 나타나 같은 종이라도 유전학적 특성이 다를 수 있으므로 균주에 따라 산업에 적용하기 위해서는 균주 고유의 생리학적 특성 규명 에 대한 추가적인 연구가 필요할 것으로 판단된다.

배양시간에 따른 균주의 성장 조사

$\mathrm{SRCM} 102046$ 의 배양시간에 따른 성장을 조사하기 위해 $500 \mathrm{~mL} \mathrm{LB}$ (Difco) 액체배지에 균주를 접종하여 60시간 동 안 $30^{\circ} \mathrm{C}, 150 \mathrm{rpm}$ 에서 배양하였으며, 4시간 단위로 배양액 의 흡광도와 건조 균체량을 측정하였다. SRCM102046은 4-20시간까지 균주가 급격히 성장하는 대수기를 보였으며, 배양 20시간 이후 성장이 점차 느려져 28시간 이후 정지기 에 도달하였다. SRCM102046의 최대성장은 24시간이었으 며, 이때 흡광도는 $1.6896(\mathrm{OD}$ at $600 \mathrm{~nm})$, 건조 균체량은 $2.47 \mathrm{~g} / \mathrm{L}$ 로 나타나 SRCM102046의 성장 최적 배양시간을 24시간으로 결정하였다(Fig. 2). 이러한 결과는 메주에서 분리된 B. subtilis $\mathrm{MJP} 1(6)$ 과 전통장류에서 분리된 $B$. subtilis SCJ1(16)이 LB(Difco) 배지에서 배양시 20시간 후 대수기를 지나 28시간 이내에 정지기에 이른다는 보고 유 사한 경향을 나타냄을 확인하였다.

\section{균체 증량을 위한 배지조성 선별}

산업적인 가치가 있는 생물자원을 다양한 산업분야에 적용하기 위해 비용적으로 저렴한 배지조성을 이용한 높은

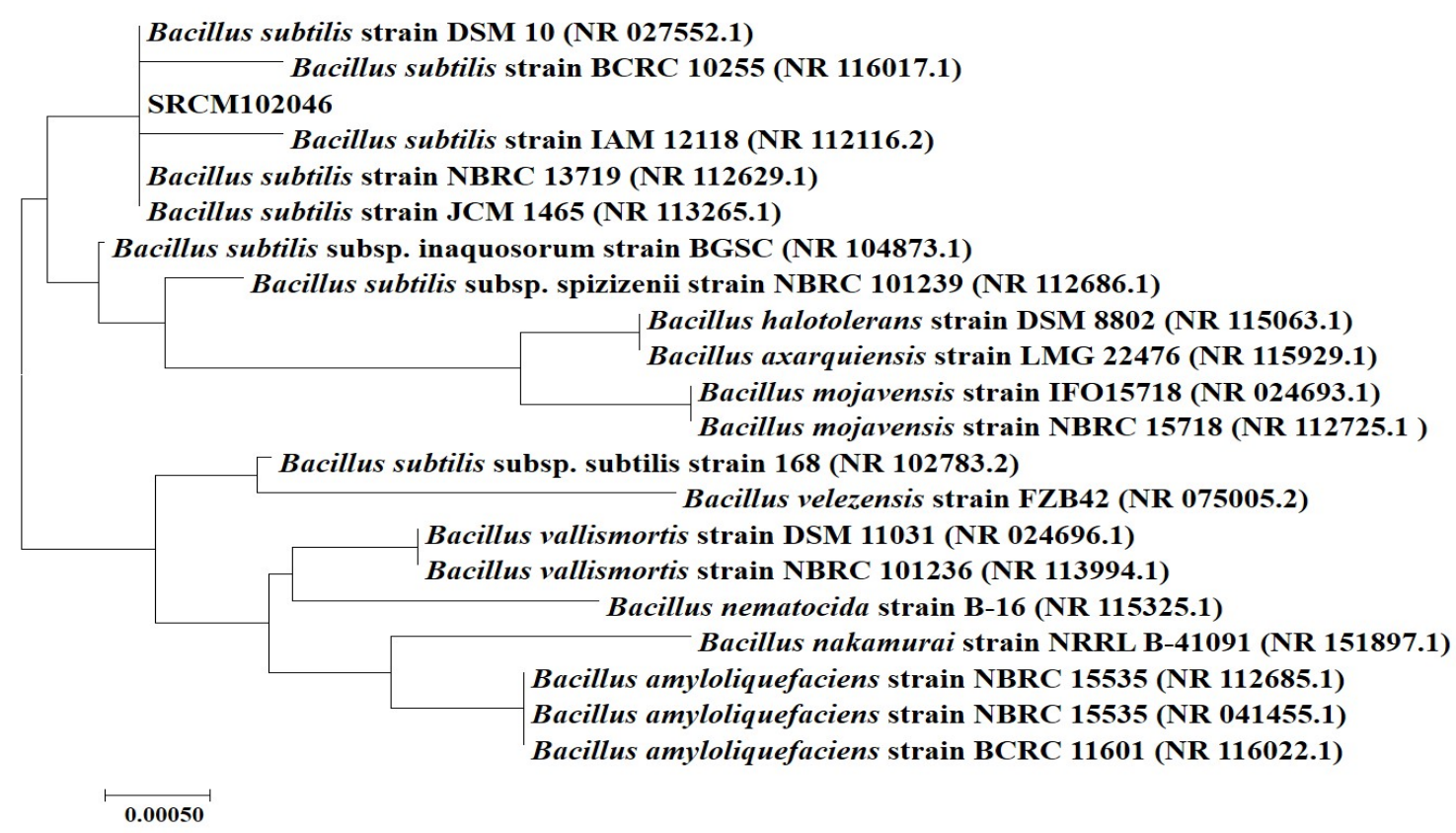

OFig. 1. Neighbor-joining phylogenetic tree based on 16S rRNA gene sequence $(1,522 \mathrm{bp})$ analysis of Bacillus subtilis affiliation of strain SRCM102046.

The evolutionary distance were calculated by the maximum composite likelihood method based on 1,000 bootstrap replication. Scale bar represents the $0.5 \%$ nucleotide substitution. 


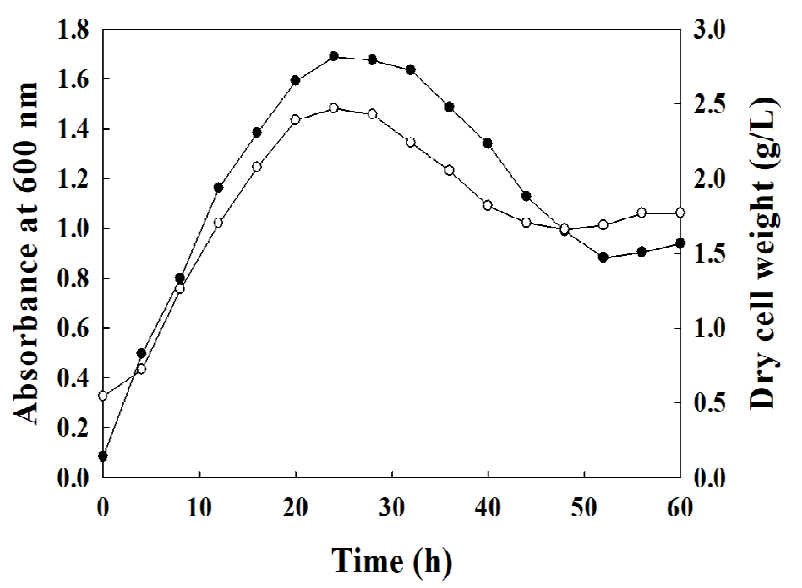

Fig. 2. Time course profile of cell growth by cells of $B$. subtilis SRCM102046 in flask culture with $150 \mathrm{rpm}$ and $30^{\circ} \mathrm{C}$.

O, OD at $600 \mathrm{~nm}$; $O$, dry cell weight $(\mathrm{g} / \mathrm{L})$.

균체생산 수율을 확립하는 것은 가장 중요한 요소 중 하나 이다. 따라서 식품보존소재로서 사용하기 위한 SRCM102046 균주의 균체 증량을 위한 가장 영향력 있는 배지성분을 선별하기 위해 $\mathrm{PBD}$ 를 적용하였다. 총 14 가지의 독립변수 중 농도가 높은 탄소원 변수로 선정된 glucose, sucrose, fructose, galacto-oligosaccharide(GOS), molasses는 중심값 으로부터 $3 \pm 2 \mathrm{~g} / \mathrm{L}$ 로, 질소원 변수로 선정된 yeast extract, beef extract, tryptone, peptone은 중심값으로부터 $2 \pm 1.5 \mathrm{~g} / \mathrm{L}$ 로, 농도가 낮은 기타 미네랄 원소는 $0.6 \pm 0.4 \mathrm{~g} / \mathrm{L}$ 로 설정하 였으며, 2 개의 중심점을 포함한 22개의 실험군에 대한 균체 량 $(\mathrm{Y}, \mathrm{g} / \mathrm{L})$ 을 Table 1 에 나타내었다. Table 1 의 결과값을 바탕으로 각 변수의 수준이 균체량에 미치는 영향을 나타내
는 plot은 Fig. 3 에 나타냈다. Molasses, sucrose, peptone은농 도가 높을수록 균체량이 증가하였으며, glucose와 fructose, yeast extract는 농도가 증가할수록 균체량이 감소하였고 다른 변수의 경우 수준 내에서 첨가량에 따른 큰 차이를 나타내지 않았다. 실험군의 반응값에 대한 각 변수들의 영 향, 모델의 계수, F-value, p-value 등 신뢰 수준에 대한 통계 분석 결과는 Table 3에 나타내었으며, 균체 증량을 위한 최적의 신뢰도를 확보하기 위해 신뢰수준이 $90 \%$ 이상이며 positive effect를 주는 변수를 주인자로 선정하였다. 균체 증량에 미치는 배지성분의 농도에 대한 plot과 신뢰수준 및 통계분석 결과에 따라 molasses, sucrose, peptone을 SRCM102046의 균체 증량을 위한 주인자로 선정하였다. Younis 등(20)에 의하면 molasses는 미생물이 자랄 수 있는 영양소와 미네랄이 풍부하고 합성배지에 비해 매우 경제적 이며, 배지성분으로 사용 시 phytase(21), protease(22)와 같 은 효소 또는 바이오에탄올(23) 등 산업적으로 유용한 대사 산물의 수율이 크게 증가한다고 보고한 바 있으므로 산업적 활용을 위한 대체 탄소원으로 매우 유용할 것으로 판단된 다.

\section{중심합성계획법에 의한 배지조성 농도의 최적화}

$\mathrm{PBD}$ 를 통해 선별한 각각의 배지 성분 농도를 최적화하 기 위해 $\mathrm{CCD}$ 를 설계하였다. 2 개의 중심점을 포함한 16 개의 실험군을 각각 3 번의 반복실험을 통한 종속변수 $(\mathrm{Y}, \mathrm{g} / \mathrm{L})$ 의 결과값은 Table 4와 같다. $\mathrm{PBD}$ 를 통해 선별된 인자의 경우 첨가량이 증가할수록 균체량이 증가하는 값을 나타내어

Table 3. Variables and their effects values from a quadratic regression equation results of Plackett-Burman design

\begin{tabular}{ccccccc}
\hline Variable $\left(\mathrm{X}_{\mathrm{i}}\right)$ & $\begin{array}{c}\text { Effect } \\
\left(\mathrm{E}_{\mathrm{x} i}\right)\end{array}$ & $\begin{array}{c}\text { Coefficient } \\
\left(\beta_{\mathrm{i}}\right)\end{array}$ & Sum of squares & F-value & p-value & Confidence level $(\%)$ \\
\hline Glucose & -4.35 & -2.17 & 94.55 & 15.11 & 0.0081 & 99.20 \\
Sucrose & 3.54 & 1.77 & 62.68 & 10.01 & 0.0195 & 98.05 \\
Fructose & -2.55 & -1.28 & 32.51 & 5.19 & 0.0629 & 93.71 \\
GOS $^{1)}$ & 1.7552 & 0.88 & 15.41 & 2.46 & 0.1677 & 83.23 \\
Molasses & 11.99 & 6.00 & 719.52 & 114.95 & $<0.0001$ & 99.99 \\
Yeast extract & -3.02 & -1.51 & 45.48 & 7.27 & 0.0358 & 96.42 \\
Beef extract & 0.72 & 0.36 & 2.62 & 0.42 & 0.5415 & 45.85 \\
Tryptone & 1.02 & 0.51 & 5.17 & 0.83 & 0.3983 & 60.17 \\
Peptone & 2.27 & 1.14 & 25.86 & 4.13 & 0.0884 & 91.16 \\
$\mathrm{NaCl}$ & 0.99 & 0.49 & 4.89 & 0.78 & 0.4109 & 58.91 \\
$\mathrm{KH}_{2} \mathrm{PO}_{4}$ & -1.39 & -0.69 & 9.61 & 1.54 & 0.2615 & 73.85 \\
$\mathrm{~K}_{2} \mathrm{HPO}_{4}$ & 0.79 & 0.40 & 3.16 & 0.51 & 0.5039 & 49.61 \\
$\mathrm{MgSO}_{4}$ & 0.86 & 0.43 & 3.68 & 0.59 & 0.4726 & 52.74 \\
$\mathrm{KCl}$ & 1.38 & 0.69 & 9.49 & 1.52 & 0.2642 & 73.58 \\
\hline
\end{tabular}

${ }^{1)} \mathrm{GOS}$, galacto-oligosaccharide. 

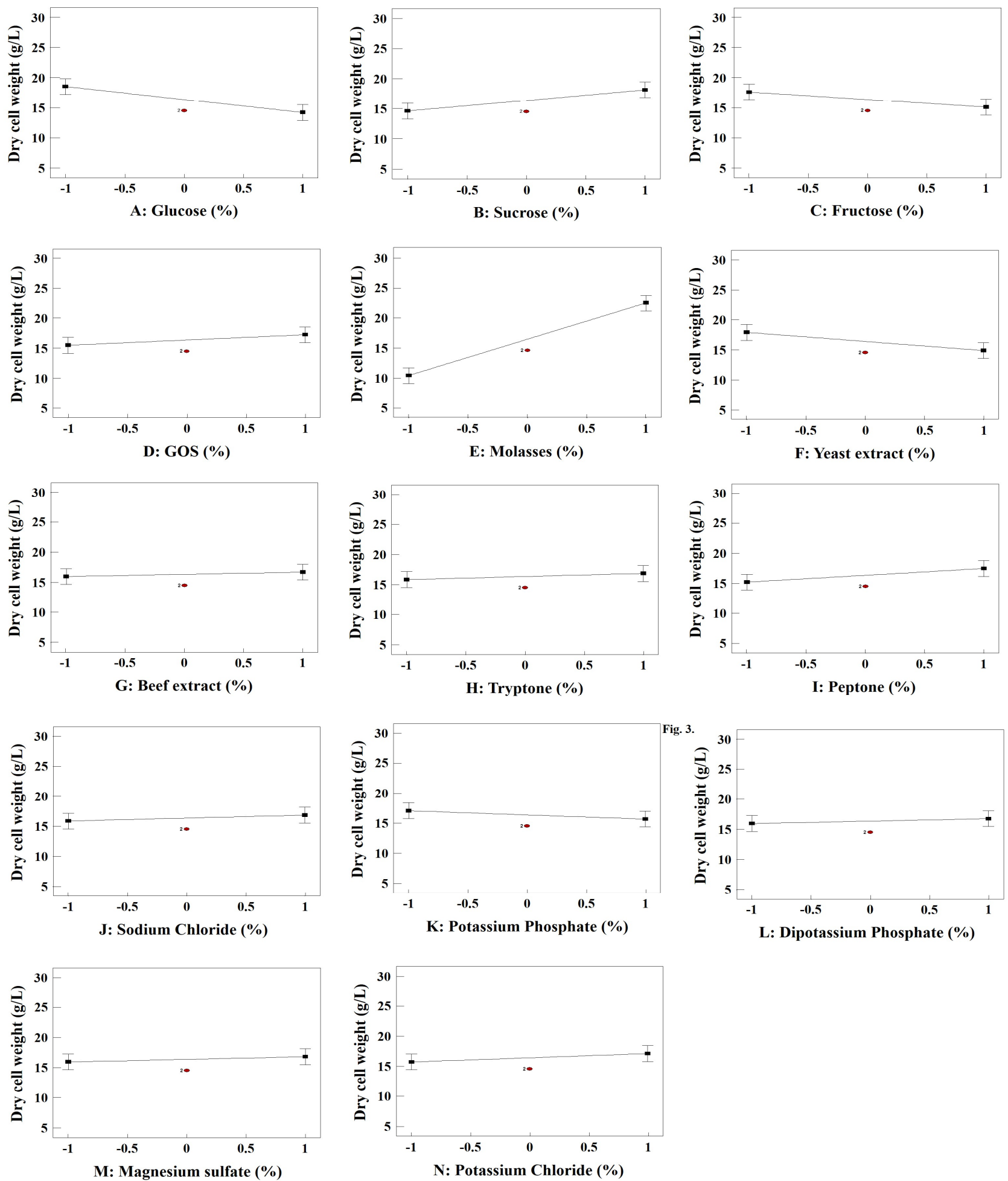

Fig. 3. Effects of media components depending on various level for biomass production.

앞선 $\mathrm{PBD}$ 에서의 +1 값을 $\mathrm{CCD}$ 의 각각 변수의 중심값으로 설정하여 수준별 변화폭을 설정하였고, 반응값에 대한 모 델식의 예측은 Design expert 9.0 program을 이용하여 분석 하였고 균체량에 대한 회귀방정식은 다음과 같다.
$\mathrm{Y}=12.26521+3.95188^{*}$ molasses $+1.71646 *$ sucrose -0.95396 * peptone $+1.59292{ }^{*}$ molasses ${ }^{*}$ sucrose $-1.00625 *$ molasses * peptone- $0.6620{ }^{*}$ sucrose ${ }^{*}$ peptone $+1.60875^{*}$ molasses 2 $+0.13708 *$ sucrose $2+0.040833 *$ peptone 
Table 4. Central composite design (CCD) and experimental results

\begin{tabular}{|c|c|c|c|c|c|c|}
\hline \multirow{2}{*}{ Factor } & \multirow{2}{*}{$\begin{array}{c}\text { Symbol } \\
\text { (unit) }\end{array}$} & \multicolumn{5}{|c|}{ Code values } \\
\hline & & -2 & -1 & 0 & +1 & +2 \\
\hline Molasses & $X_{1}(g / L)$ & 1.0 & 3.0 & 5.0 & 7.0 & 9.0 \\
\hline Sucrose & $\mathrm{X}_{2}(\mathrm{~g} / \mathrm{L})$ & 1.0 & 3.0 & 5.0 & 7.0 & 9.0 \\
\hline Peptone & $\mathrm{X}_{3}(\mathrm{~g} / \mathrm{L})$ & 0.5 & 2.0 & 3.5 & 5.0 & 6.5 \\
\hline Runs & $X_{1}$ & & $\mathrm{X}_{2}$ & $\mathrm{X}_{3}$ & & $\mathrm{Y}^{1)}, \mathrm{DCW}(\mathrm{g} / \mathrm{L})$ \\
\hline 1 & -1 & & +1 & +1 & & 11.443 \\
\hline 2 & +1 & & -1 & -1 & & 14.737 \\
\hline 3 & +1 & & +1 & -1 & & 23.667 \\
\hline 4 & 0 & & 0 & 0 & & 12.067 \\
\hline 5 & +1 & & -1 & +1 & & 16.267 \\
\hline 6 & -1 & & -1 & -1 & & 7.44 \\
\hline 7 & -2 & & 0 & 0 & & 11.807 \\
\hline 8 & 0 & & 0 & -2 & & 9.813 \\
\hline 9 & -1 & & -1 & +1 & & 11.533 \\
\hline 10 & +1 & & +1 & +1 & & 21.087 \\
\hline 11 & +2 & & 0 & 0 & & 25.020 \\
\hline 12 & -1 & & +1 & -1 & & 8.537 \\
\hline 13 & 0 & & -2 & 0 & & 9.350 \\
\hline 14 & 0 & & 0 & 0 & & 11.890 \\
\hline 15 & 0 & & 0 & +2 & & 14.470 \\
\hline 16 & 0 & & +2 & 0 & & 15.703 \\
\hline
\end{tabular}

All experiments were performed in triplicate.

${ }^{1)} Y$, response value, dry cell weight of $B$. subtilis SRCM102046

(A)

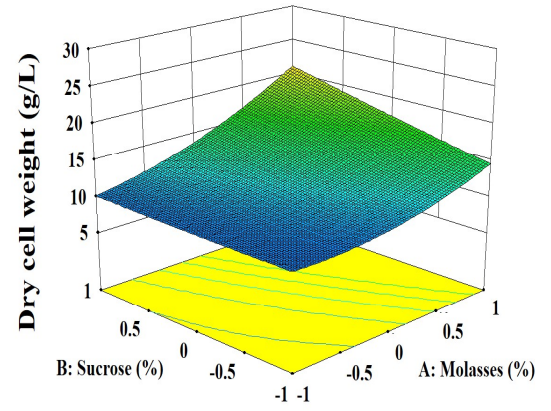

(B)

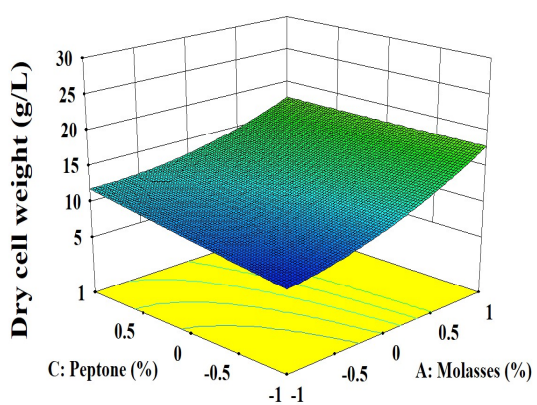

(C)

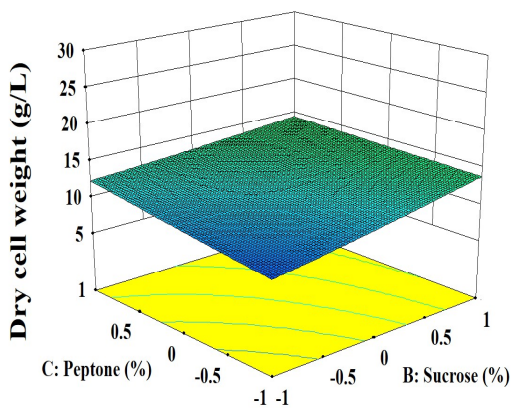

Fig. 4. Three-dimensional response surface plot of dry cell weight by B. subtilis SRCM102046.

A, dry cell weight production by molasses $\left(\mathrm{X}_{1}\right)$ and sucrose $\left(\mathrm{X}_{2}\right)$; B, dry cell weight production by molasses $\left(\mathrm{X}_{1}\right)$ and peptone $\left(\mathrm{X}_{3}\right)$; $\mathrm{C}$, dry cell weight production by suctose $\left(\mathrm{X}_{2}\right)$ and peptone $\left(\mathrm{X}_{3}\right)$.

분산분석 결과 전체 모델의 F-value가 26.50으로 나타나 가정된 실험 모델이 적합함을 확인하였으며, $\mathrm{p}$-value가 0.0004로 통계적으로 매우 유의한 범위에 존재하였다. 또한 결정계수 $\left(\mathrm{R}^{2}\right)$ 는 0.9755 로서 실제값과 실험 모델에 의해 예 측된 값이 거의 일치함을 확인할 수 있었으며, 종속변수의
평균값에 대한 오차제곱합의 제곱근을 나타내는 변동계수 (CV, coefficient of variation)는 9.23으로 변수들 간의 상호 작용과 독립적인 영향이 매우 높게 작용하고 있음을 나타냈 다(Table 5). 선별된 각 독립변수가 다른 독립변수에 미치는 영향을 확인하기 위해 3 개의 변수 중 하나의 독립변수를 
Table 5. Summarized data of analysis of variance (ANOVA) for enhancing biomass production according to response surface methodology (RSM)

\begin{tabular}{|c|c|c|c|c|c|c|c|}
\hline Sources & Coefficient estimate & Sum of squares & Degree of freedom & Mean square & Standard error & F-value & $p$-value, Prob $>F$ \\
\hline Model & 12.27 & 401.42 & 9 & 44.60 & 0.86 & 26.50 & $0.0004^{* * * * 4)}$ \\
\hline $\mathrm{X}_{1}^{1)}$ & 3.95 & 249.88 & 1 & 249.88 & 0.32 & 148.44 & $<0.0001^{* * * *}$ \\
\hline $\mathrm{X}_{2}^{2)}$ & 1.72 & 47.14 & 1 & 47.14 & 0.32 & 28.00 & $0.0018^{* * *}$ \\
\hline $\mathrm{X}_{3}^{3)}$ & 0.95 & 14.56 & 1 & 14.56 & 0.32 & 8.65 & $0.0259^{* *}$ \\
\hline $\mathrm{X}_{1} \mathrm{X}_{2}$ & 1.59 & 20.30 & 1 & 20.30 & 0.46 & 12.06 & $0.0133^{* *}$ \\
\hline$X_{1} X_{3}$ & -1.01 & 8.10 & 1 & 8.10 & 0.46 & 4.81 & $0.0707^{*}$ \\
\hline $\mathrm{X}_{2} \mathrm{X}_{3}$ & -0.66 & 3.51 & 1 & 3.51 & 0.46 & 2.08 & 0.1990 \\
\hline $\mathrm{X}_{1}^{2}$ & 1.61 & 41.41 & 1 & 41.41 & 0.32 & 24.60 & $0.0026^{* * *}$ \\
\hline $\mathrm{X}_{2}^{2}$ & 0.14 & 0.30 & 1 & 0.30 & 0.32 & 0.18 & 0.6873 \\
\hline $\mathrm{X}_{3}^{2}$ & 0.041 & 0.027 & 1 & 0.027 & 0.32 & 0.016 & 0.9039 \\
\hline Residual & & 10.10 & 6 & 1.68 & & & \\
\hline Lack of fit & & 10.08 & 5 & 2.02 & & & \\
\hline Pure error & & 0.016 & 1 & 0.016 & & & \\
\hline Cor Total & & 411.52 & 15 & & & & \\
\hline & Standard deviation & & 1.30 & & Press & & 84.70 \\
\hline & Mean & & 14.05 & & $\mathrm{R}$-squared & & 0.9755 \\
\hline \multicolumn{3}{|c|}{ Coefficient of variation (\%) } & 9.23 & & Adjusted R-squared & & 0.9386 \\
\hline
\end{tabular}

\footnotetext{
${ }^{1)} X_{1}$, molasses.

${ }^{2)} \mathrm{X}_{2}$, sucrose.

${ }^{3)} X_{3}$, peptone.

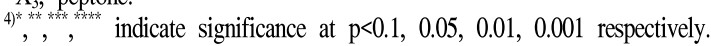

최적점에 고정하고 나머지 2개의 변수를 이용한 3차원 등 고선으로 교호작용을 나타낸 결과, 설정 범위 내에서 중심 값으로부터 molasses, sucrose, peptone의 농도가 높아질수 록 균체량이 증가함을 확인하였다(Fig. 4). 최종적으로 $\mathrm{CCD}$ 를 기반으로 SRCM102046의 균체 증량에 영향을 주는 주요 인의 농도를 예측하였고 모델에 의해 예측된 SRCM102046 의 최대 균체량을 생산하기 위한 배지조성의 농도는 molasses $7 \mathrm{~g} / \mathrm{L}$, sucrose $7 \mathrm{~g} / \mathrm{L}$, peptone $2 \mathrm{~g} / \mathrm{L}$ 로 나타났으며, 이때의 최대 균체량은 $22.03 \pm 1.30 \mathrm{~g} / \mathrm{L}$ 로 예측되었다.

\section{실험모델의 검증}

중심합성계획법에 의해 예측된 최적 배지에서의 $\mathrm{SRCM} 102064$ 의 균체 성장을 검증하기 위해 실험모델에 의해 예측된 최적 배지에 접종하여 건조 균체량을 측정하였 다. 배양액의 건조 균체량을 측정한 결과 $22.02 \pm 0.35 \mathrm{~g} / \mathrm{L}$ 로 측정되었으며, 실험모델에 의해 예측된 값인 $22.03 \pm 1.30$ $\mathrm{g} / \mathrm{L}$ 의 오차범위 내에 존재하여 실험모델에 의해 예측된 값과 실험에 의한 값이 동일함을 확인하였으며, 이는 대조 구로 사용된 LB(Difco) 배지에서의 균체량 $2.47 \pm 0.03 \mathrm{~g} / \mathrm{L}$ 에 비해 약 9 배의 균체량 증량에 해당하는 수준으로 나타났다 (Fig. 5). 이전의 연구결과 $(6,14,16)$ 에 의하면 B. subtilis의 균체 생산량은 배지 성분이나 농도, 배양시간 등 물리적

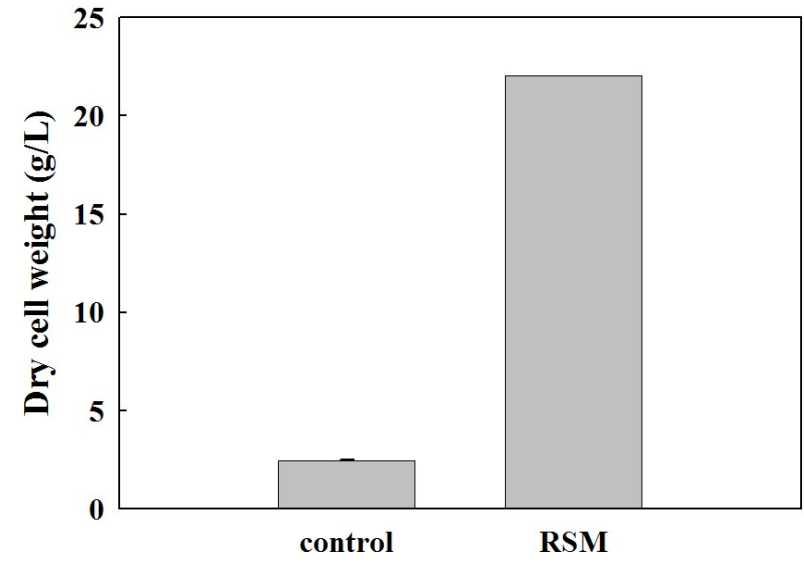

Fig. 5. Dry cell weight comparison between control (LB, non-optimized basal medium) and optimized medium.

Experiments were carried out in triplicate (Duncan's multiple range test at $\mathrm{p}<0.05$ ).

요인에 따라 크게 달라질 수 있으며, Jeong 등(24)은 통계학 적 방법이 적용된 발효공정을 통한 Bacillus 종의 균체 생산 량이 최대 10 배 증가하였다 보고하고 있어 이보다는 다소 낮은 균체 성장률을 보였으나, 물리적 요인을 배제한 배지 성분의 최적화만을 통해서도 최종적으로 균체 성장이 약 9배 증가하여 향후 추가적 외부 요인에 대한 연구가 진행된 
다면 더 높은 균체 성장이 가능할 것으로 판단된다.

\section{식품유해미생물에 대한 항균활성 측정}

식품 안전성에 대한 소비자들의 관심으로 인하여 식품유 해미생물 증식을 억제할 목적으로 기존에 사용되던 화학합 성 보존제를 대체할 천연화합물들이 선호되고 있으며, 이 에 따라 신규 박테리오신들에 대한 개발 및 식품에서의 응용에 필요한 연구들이 이루어지고 있다(25). 특히, Bacillus 속의 균주들은 iturin, surfactin, fengycin, plipastatin 등과 같은 lipopeptide를 생산하는 것으로 알려져 있어 생물 학적 방제의 적용에 잠재적 가치를 지닌 생물자원으로 알려 져 있다(26). 본 연구에서는 8종의 gram 양성균과 6종의 음성균, 2종의 Aspergillus flavus를 대상으로 SRCM102046 에 의한 식품유해미생물의 저해 여부와 최적배지에서의 활성 증가를 조사하여 식품보존제로서 활용 가능성에 대한 연구를 진행하였다(Table 6). 사용된 지시균주 중 Escherichia coli KCCM12177과 Salmonella typhimurium KCTC1926, Aspergillus flavus var. flavus KCCM60330를 제외한 모든 지시균들에 대한 저해활성을 보였으며, 최적성장배지에서 대조구 대비 gram 양성균에 대한 항균활성은 17.64$64.29 \%$, gram 음성균에 대한 항균활성은 $90-140 \%$ 증가하 였다. SRCM102046은 gram 음성균보다 양성균에 대한 저 해 범위가 넓은 것으로 나타났으며, 특히 심내막염, 패혈증, 요로감염증을 일으키는 것으로 알려진 Enterococcus

Table 6. Antimicrobial spectra of the B. subtilis SRCM102046

\begin{tabular}{|c|c|c|c|}
\hline & \multirow[b]{2}{*}{ Indicator organism } & \multicolumn{2}{|c|}{ Inhibition zone $(\mathrm{mm})$} \\
\hline & & $\mathrm{LB}^{1)}$ & $\begin{array}{c}\text { Optimized } \\
\text { medium }\end{array}$ \\
\hline \multirow{8}{*}{$\begin{array}{c}\text { Gram } \\
\text { positive }\end{array}$} & Bacillus cereus КСТС3624 & 10 & 22 \\
\hline & Bacillus cereus $\mathrm{KCCM} 40935$ & 10 & 20 \\
\hline & Staphylococcus aureus KCCM11335 & 14 & 17 \\
\hline & Staphylococcus aureus KCCM40050 & 11 & 13 \\
\hline & Enterococcus faecalis KCCM11814 & 17 & 20 \\
\hline & Listeria monocytogenes KCCM43155 & 20 & 24 \\
\hline & Listeria ivanovii КСТС 3444 & 15 & 21 \\
\hline & Micrococcus luteus KCCM11211 & 14 & 23 \\
\hline \multirow{6}{*}{$\begin{array}{c}\text { Gram } \\
\text { negative }\end{array}$} & Shigella flexneri KCTC2517 & 11 & 24 \\
\hline & Shigella sonnei $\mathrm{KCTC} 2518$ & 10 & 19 \\
\hline & Klebsiella pneumoniae KCCM40890 & 10 & 24 \\
\hline & Vibrio parahaemolyticus KCCM11965 & 8 & 16 \\
\hline & Escherichia coli KCCM12177 & -2) & - \\
\hline & Salmonella typhimurium $\mathrm{KCTC1926}$ & - & - \\
\hline \multirow{2}{*}{ Mold } & Aspergillus flavus KCCM11910 & 9 & 9 \\
\hline & Aspergillus flavus var. flavus КССМ60330 & - & - \\
\hline
\end{tabular}

\footnotetext{
${ }^{1)} \mathrm{LB}$, non-optimized basal medium as control.
}

${ }^{2)}$, no inhibition. faecalis KCCM11814와 뇌수막염, 뇌염, 폐렴 등의 원인균 으로 알려진 Listeria monocytogenes KCCM43155에 대한 저해 효과가 가장 큰 것으로 나타났다. 이와 반대로 성장 장애, 발달 지연, 간암 등의 원인으로 알려진 aflatoxin $\mathrm{B}_{1}$, $\mathrm{B}_{2}$ 를 생산(27)하는 것으로 알려진 Aspergillus flavus 2 종에 대한 항균활성이 미미하거나 나타나지 않았으며, 최적성장 배지에서도 항균활성이 증가하지 않거나 나타나지 않았다. 이러한 결과는 Bacillus의 항균 활성이 Aspergillus flavus에 대한 항균활성은 미미하지만 gram 양성균, 특히, Listeria에 강한 항균 활성을 나타낸다는 이전의 연구 $(25,28)$ 와 유사하 였으며, B. subtilis의 균체 증량을 위한 배지 최적화시 Bacillus cereus, Listeria moconcytogenes 등에 대한 항균활 성이 40-50\% 증가한다는 연구결과(14)와 동일하게 균체량 증가를 통하여 SRCM102046의 항균 활성 또한 증가함을 확인하였다.

\section{항산화활성 측정}

식품보존제로서의 역할 이외에도 식품내 다양한 분야의 활용을 위해서는 항산화 활성 또한 매우 중요한 부분을 차지하고 있다. 하지만 식품 산화를 억제시키는 항산화 활 성을 가진 미생물을 탐색한 연구결과 Aspergillus oryzae 또는 Saccharomyces cerevisiae와 같은 곰팡이와 효모, Lactobacillus bulgaricus 세포 배양액에서 항산화 효과가 있는 것으로 보고(29)된 바 있으나, 우리나라 발효식품의 발효과정에 많이 관여하는 것으로 알려진 Bacillus속 유래 의 항산화 물질 생성에 관한 연구는 많이 알려져 있지 않다. SRCM102046 배양액의 항산화 활성을 $\mathrm{DPPH}$ 법에 의한 전 자공여능으로 측정한 결과(Fig. 6) 대조구로 사용된 $\mathrm{LB}$ (Difco) 배지에서 배양시 $24.46 \pm 0.9 \%$ 로 나타나 Lee 등 (30)에 의해 보고된 Bacillus sp. B-59 균주의 최대 활성인 $17 \%$ 보다 비교적 우수한 것으로 나타났다. 또한 최적 배지

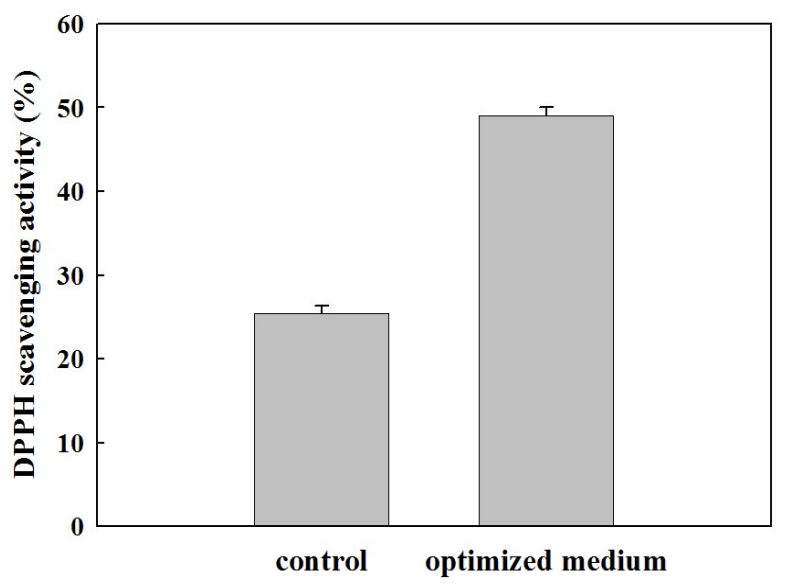

Fig. 6. The comparison of antioxidant activity between control (LB, non-optimized basal medium) and optimized medium.

Experiments were carried out in triplicate (Duncan's multiple range test at $\mathrm{p}<0.05$ ). 
에서의 항산화 활성은 $49.02 \pm 0.99 \%$ 로 이는 활성이 약 2 배 증가한 수준이며, B. subtilis SCJ4의 항산화능이 배지 최적 화 수행시 $7.59 \%$ 에서 $23.16 \%$ 로 약 3 배 증가하였다는 연구 결과(14)와 동일하게 배양 조건 최적화를 통해 항산화 활성 또한 향상되는 결과를 얻을 수 있었다. 특히, 항산화 활성의 경우 배지 최적화를 통해 선별된 비정제 사탕수수 당인 molasses의 첨가로 인해 식물에 다량 존재하는 항산화 물질 이 최적화를 통하여 최적화 전과 비교해 증가의 요인으로 작용한 것으로 판단된다.

배지성분은 균체의 생산성에 직결되는 중요한 요인이며, 각 배지 성분의 농도 또한 매우 밀접한 관련이 있다(24). 따라서 본 연구에서는 넓은 범위의 항균활성과 높은 항산화 능을 가지는 B. subtilis SRCM102046의 산업적 적용을 위해 반응표면분석법을 적용하여 향상된 균체생산량과 이에 따 라 증가된 항균활성 및 항산화활성을 확인하였다. 본 연구 에서 확립된 자료는 미생물을 이용한 식품보존제 생산을 위한 유용한 자료로 활용될 수 있을 것이라 판단된다.

\section{요 약}

본 연구에서는 다양한 식품유해미생물에 대한 길항작용 및 항산화활성이 우수한 B. subtilis SRCM102046 균주를 식품보존 소재로서 이용하기 위해 반응표면분석법을 이용 하여 균체 증량을 통한 항균활성 및 항산화활성 증대를 도모하고자 하였다. SRCM102046의 산업적 활용을 위한 성장조건을 최적화하기 위해 배양시간에 따른 균체 성장을 조사하였으며, 통계학적 기법인 반응표면분석법을 사용하 였다. SRCM102046의 최적 성장을 위한 배지 성분을 선별 하기 위해 Plackett-Burman design을 이용하였으며, PBD 결과 선별된 배지 성분으로 molasses, sucrose, peptone으로 예측되었다. 각 배지 성분의 최적농도를 결정하기 위한 방 법으로 central composite design을 이용하였으며, 최종적으 로 예측된 각 배지 성분의 농도는 molasses $7 \mathrm{~g} / \mathrm{L}$, sucrose $7 \mathrm{~g} / \mathrm{L}$, peptone $2 \mathrm{~g} / \mathrm{L}$ 로 예측되었다. 이때의 균체량은 $22.03 \pm 1.30 \mathrm{~g} / \mathrm{L}$ 로 예측되었으며, 통계분석을 통해 실험모 델의 적합성을 확인하였다. 또한, 실험 모델을 수행하여 건조균체량을 측정한 결과 $22.02 \pm 0.35 \mathrm{~g} / \mathrm{L}$ 로 측정되어 실험 모델에 의해 예측된 값이 오차범위 내에 존재하여 모델의 신뢰성이 매우 높음을 확인하였으며, 이는 실험모델에 의 해 예측된 최적배지 사용시 최적화 이전의 LB 배지에서의 균체량 $(2.47 \pm 0.03 \mathrm{~g} / \mathrm{L})$ 대비 약 9 배의 균체량이 증가함을 확인하였다. 또한 최적배지에서 B. subtilis SRCM102046 배양 시 항균활성은 대조구로 사용된 LB 배지에서의 항균 활성 대비 최대 $140 \%$ 향상되었으며, 항산화활성은 약 $100.41 \%$ 증가함을 확인하였다. 본 연구를 통하여 식품보존 제로서 B. subtilis SRCM102046의 산업화를 위한 배지최적
화를 수행하였으며, 추후 박테리오신의 정제 및 특성 등에 대한 세부적인 연구가 필요하지만 본 연구를 통해 확립된 배양조건을 기반으로 식품보존 소재의 측면에서 매우 유용 한 자료로 활용될 수 있을 것으로 기대된다.

\section{감사의 글}

본 연구는 2018년 산업통상자원부 산업기술거점기관지 원(한국형 유용균주, 과제번호: R0004073) 사업의 지원에 의해 수행되었습니다.

\section{References}

1. Ahn DJ, Kwak YS, Kim MJ, Lee JC, Shin CS, Jeong KT (2000) Screening of herbal plant extracts showing antimicrobial activity against some food spoilage and pathogenic microorganisms. Korean J Med Crop Sci, 8, 109-116

2. Oh DH, Ham SS, Park BK, Ahn C, Yu JU (1998) Antimicrobial activities of natural medicinal herbs on the food spoilage or foodborne disease microorganisms. Korean J Food Sci Technol, 30, 957-963

3. Lim SI, Song SM (2010) Fermentation properties of low-salted Doenjang supplemented with licorice, mustard, and chitosan. Korean J Food Sci Technol, 42, 323-328

4. Kang KJ, Jeoung JH, Cho JI (2000) Inhibition of aflatoxin-producing fungi with antifungal compound produced by Bacillus subtilis. J Food Hyg Saf, 15, 122-127

5. Lee JY, Shim JM, Lee KW, Cho KM, Kim GM, Shin JH, Kim JS, Kim JH (2016) Inhibition of Bacillus cereus in Doenjang fermented with multiple starters showing inhibitory activity against pathogens. Microbiol Biotechnol Lett, 44, 254-260

6. Yang EJ, Chang HC (2007) Characterization of bacteriocin-like substances produced by Bacillus subtilis MJP1. Korean J Microbiol Biotechnol, 35, 339-346

7. Kim SI, Chang JY, Kim IC, Chang HC (2001) Characterization of bacteriocin from Bacillus subtilis $\mathrm{cx} 1$. Korean J Microbiol Biotechnol, 29, 50-55

8. Lim KB, Balolong MP, Kim SH, Oh JK, Lee JY, Kang DK (2016) Isolation and characterization of a broad spectrum bacteriocin from Bacillus amyloliquefaciens RX7. BioMed Res Int, 2016, Article 8521476 
9. Cha HA, Chung D, Hong SW, Chung KS (2014) Purification and characterization of an antimicrobial substance from Bacillus subtilis $\mathrm{HH} 28$ antagonistic to Bacillus cereus. Korean J Microbiol Biotechnol, 42, 393-401

10. Sharma N, Kapoor R, Gautam N, Kumari R (2011) Purification and characterization of bacteriocin produced by Bacillus subtilis R75 isolated from fermented chunks of mung bean (Phaseolus radiatus). Food Technol Biotechnol, 49, 169-176

11. Lee SG, Chang HC (2018) Purification and characterization of mejucin, a new bacteriocin produced by Bacillus subtilis SN7. LWT-Food Sci Technol, 87, 8-15

12. Xie J, Zhang R, Shang C, Guo Y (2009) Isolation and characterization of a bacteriocin produced by an isolated Bacillus subtilis LFB112 that exhibits antimicrobial activity against domestic animal pathogens. Afr J Biothenol, 8, 5611-5619

13. Ahn HJ, Jeong YS, Kim PH, Chun GT (2007) Mass screening of lovastatin high-yielding mutants through statistical optimization of sporulation medium and application of miniaturized fungal cell cultures. KSBB J, 22, 297-304

14. Jeong SJ, Yang HJ, Jeong SY, Jeong DY (2015) Identification of characterization and statistical optimization of medium constituent for Bacillus subtilis SCJ4 isolated from Korean traditional fermented food. Korean J Microbiol, 51, 48-60

15. Saitou N, Nei M (1987) The neighbor-joining method: a new method for reconstructing phylogenetic trees. Mol Biol Evol, 4, 406-425

16. Yang HJ, Jeong SJ, Jeong SY, Heo JH, Choi NS, Jeong DY (2016) Screening of non-biogenic-amine-producing Bacillus subtilis and medium optimization for improving biomass by the response surface methodology. J Life Sci, 26, 571-583

17. Magaldi S, Mata-Essayag S, Hartung de Capriles C, Perez C, Colella MT, Olaizola C, Ontiveros Y (2004) Well diffusion for antifungal susceptibility testing. Int J Infect Dis, 8, 39-45

18. Blois MS (1958) Antioxidant determinations by the use of a stable free radical. Nature, 181, 1199-1200

19. Earl AM, Losick R, Kolter R (2006) Bacillus subtilis genome diversity. J Bacteriol, 189, 1163-1170
20. Younis MAM, Hezayen FF, Nour-Eldein MA, Shabeb MSA (2009) Production of protease in low-cost medium by Bacillus subtilis $\mathrm{KO}$ strain. Global J Biotechnol Biochem, 4, 132-137

21. Vohra A, Satyanarayana T (2004) A cost-effective cane molasses medium for enhanced cell-bound phytase production by Pichia anomala. J Appl Microbiol, 97, 471-476

22. Lakshmi BKM, Hemalatha KPJ (2015) Response surface optimization of medium composition for alkaline protease production by Bacillus cereus strain S8. Int J Pure App Biosci, 3, 216-223

23. Thenmozhi R, Victoria J (2013) Optimization and improvement of ethanol production by the incorporation of organic wastes. Adv Appl Sci Res, 4, 119-123

24. Jeong YM, Lee JH, Chung HJ, Chun GT, Yun SI, Jeong YS (2010) Optimization of medium and fermentation conditions for mass production of Bacillus licheniformis SCD121067 by statistical experimental design. KSBB J, 25, 539-546

25. Kwon GH, Lee HA, Kim JH (2010) A bacteriocin of $5-\mathrm{kDa}$ in size secreted by Bacillus subtilis 168 . Korean J Microbiol Biotechnol, 38, 163-167

26. Yoon SH, Kim JB, Lim YH, Hong SR, Song JK, Kim SS, Kwon SW, Park IC, Kim SJ, Yeo YS, Koo BS (2005) Isolation and characterization of three kinds of lipopeptides produced by Bacillus subtilis JKK238 from Jeot-Kal of Korean traditional fermented fishes. Korean J Microbiol Biotechnol, 33, 295-301

27. Do JH, Choi DK (2007) Aflatoxins: detection, toxicity, and biosynthesis. Biotechnol Bioprocess Eng, 12, 585-593

28. Shim HS, Kim MD (2016) Antipathogenic activity of Bacillus amyloliquefaciens isolated from Korean traditional rice wine. Microbiol Biotechnol Lett, 44, 98-105

29. Cha JY, Kim HJ, Jeon BS, Park JC, Ok M, Cho YS (2003) Antioxidative activity and produced condition of antioxidative substance by Bacillus sp. FF-7. J Korean Agric Chem Soc, 46, 165-170

30. Lee SH, Baek LM, Park LY (2008) Physiological characteristics of Bacillus spp. isolated from rice straw as Cheonggukjang starter. Korean J Food Sci Technol, 40, 562-567 